\title{
Halal Tourism: Between Economic Opportunities and Social Acceptance
}

\author{
Madziatul Churiyah, Heri Pratikto, Filianti and Muhammad Fikri Akbar \\ Faculty of Economy Universitas Negeri Malang, Jalan Semarang 5, Malang 65145, Indonesia \\ Correspondence should be addressed to Madziatul Churiyah; madziatul.churiyah.fe@um.ac.id
}

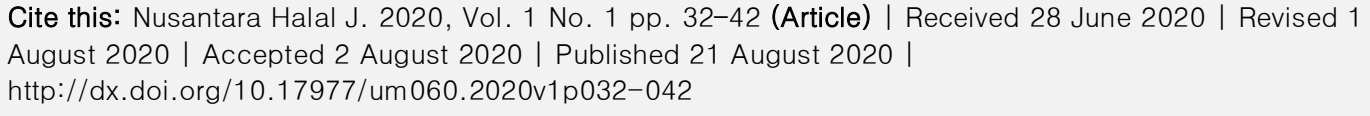

\begin{abstract}
Halal Tourism trends encounter improvement due to the increasing number of Muslim tourists who travel to various countries and spend an exceptional amount of funds every year. Halal Tourism positively affects countries' economic growth, including Indonesia. GMTI 2019 places Indonesia as the best Halal Tourism destination. Consequently, the Indonesia government is continuously working on this promising economic opportunity by developing Halal Tourism destinations in several areas. However, what has been projected by the Indonesia government to grab this global economic opportunity faces social rejections. This study aims to analyze the economic opportunity of the Halal Tourism trend and the acceptance from Indonesia's society affected by this project development. The literature analysis reveals that Indonesia society refuses the Halal Tourism concept due to the low comprehension of the Halal Tourism concept. Thus, education on Halal Tourism should be conducted, and focused segmentation of Halal Tourism destination is urgent to be completed.
\end{abstract}

Keywords: Halal tourism, social acceptance, Muslim tourists, economic opportunities.

\section{Introduction}

The Halal Tourism trend opens up a number of opportunities for many countries, one of which is Indonesia, such as economic opportunities and the promotion of natural and cultural wealth. Halal Tourism plays an essential role in economic growth because it is able to create millions of jobs to increase national income [1-3]. Indonesia is making a lot of revenue from the Halal Tourism sector. Thomson Reuters, in collaboration with Dinar Standard, made a report titled "State of the Global Islamic Economy 2018/2019." They said that in 2017 Muslim tourists have spent the usual amount of US $\$ 177$ billion and will experience an increase every year so that by 2023 its spending costs will reach US $\$ 274$ billion. Indonesia also felt the effects of spending on 
Muslim tourists from various parts of the world. Indonesia occupies the fourth position after Malaysia, UAE, and Turkey as the country with the most significant income through Halal Tourism [4]. The latest report states that through the Halal Tourism market, which grew 15\%, Indonesia won 2.8 million Muslim tourist visits and generated a foreign exchange of more than 30 trillion Rupiah [5].

GMTI (Global Muslim Travel Index) 2019 named Indonesia as the best Halal Tourism destination in the world. Indonesia, which has the largest Muslim majority population in the world and extraordinary natural and cultural riches, agrees with the coronation [6]. The government also welcomes this coronation and continues to strive to develop Halal Tourism. Currently, through [7], The government has focused on developing Halal Tourism destinations in eight provinces, namely Aceh, North Sumatra, West Java, East Java, Yogyakarta, West Nusa Tenggara, South Sulawesi, and South Kalimantan. The selection of these eight provinces is based on the finding of abundant natural resources, tourism, culinary, and culture so that this potential is expected to accelerate the development of Halal Tourism destinations. In North Sumatra, one of the projected destinations is Lake Toba which is the largest lake in Southeast Asia and as the largest volcanic lake in the world. In terms of the community environment, the majority of the population around Lake Toba is a Christian Batak tribe.

The North Sumatra Provincial Government is projecting Lake Toba as a Halal Tourism destination that impacts on the regulation of selling pork-based food [8]. This is intended to attract tourists from neighboring countries such as Brunei Darussalam and Malaysia. In the same year, the Minister of Tourism and Creative Economy also voiced about developing Halal Tourism in Bali, a province that is predominantly inhabited by Hindus [9]. Communities around the two regions responded in the form of rejection. The community around Lake Toba even made a celebration of the Lake Toba Pig Festival which contained activities in the form of pig racing, pig selfies to debauchery to eat pork dishes to celebrate the rejection of the planned development of Halal Tourism on Lake Toba by the North Sumatra Provincial Government [10]. The same thing happened in Bali; many people, government figures, and tourism figures rejected the plan to develop Halal Tourism in Bali. One of the government figures said the idea could not be accepted because Bali was already well-known and would continue to maintain its branding as Cultural Tourism, not religious tourism [9].

The emergence of a rejection reaction from the community around the development of Halal Tourism destinations by the Indonesian government is very unfortunate. The primary purpose of developing Halal Tourism destinations is not to replace what already exists, but only to try to provide amenities and everything to create a Halal Tourism destination that can accommodate the needs of Muslim tourists from various worlds. That is because Halal Tourism plays a vital role in economic growth and provides employment for the surrounding community [11,12]. The purpose of this study is to analyze the economic opportunities that come from Halal Tourism and the reaction of the majority of people who reject it. This research will have a positive impact on the broader community of Indonesia in the form of providing a real understanding of the concept of Halal Tourism and the opportunities brought from it. While to the Indonesian government, this research is essential as an effort to clarify to the broader community and for 
businesses engaged in the field of Halal Tourism, it can be used as a reference as a projection for the development of future Halal Tourism business.

\section{Literature Review}

\section{Halal Tourism Concept}

Islam is perhaps the unique religion in the world and brings Muslims (adherents) to follow what has been taught through the Koran (the word of God that is Allah SWT) and the Hadith (all the words, behavior and silence of Muhammad SAW as the last Apostle). The Qur'an contains guidelines and arrangements for all aspects of life and human activities so that the role of Islam also influences Muslim travel [13-16]. Along with the times, Muslims are increasingly aware of this position, and they are trying to choose tourist destinations that can accommodate the needs of worship while carrying out tourist trips such as the availability of halal food, Muslim-friendly hotels, and destinations that do not display pornography or the like. Halal is a compulsory choice for Muslims, which does not only cover food matters. Therefore, the development of Halal Tourism destinations must be guided by teachings and principles in accordance with Islamic law; this includes all aspects of tourism activities [2]. Interpret halal as whatever is permitted in Islam. Whereas in Arabic, halal is used in the Koran and has the same meaning as said [17], those are things or actions that are permitted by Islamic law, in this case, sharia law [18]. Therefore Halal Tourism is everything that is covered in tourism and is ensured to be in harmony with Islamic laws.

At present, there are many definitions of Halal Tourism; some even mention it in the term Islamic Tourism although, in conclusion, it is agreed that the use of the word Halal Tourism is more suitable [19]. States Halal Tourism as a travel tour carried out by Muslims based on Islamic law relating to the selection of destinations and activities carried out by Muslims in it [20]. Carboni et al. also stated the same thing by adding the efforts of Muslims to maintain religious orders during the trip, which means that the choice of destination does not have to be in a place with a Muslim majority population [21]. Vargas-Sánchez et al. also provides a definition of Halal Tourism as a tour that is carried out for recreational and social purposes and is based on spiritual motivation or not, but Muslims who travel continue to try to adjust their activities to remain in accordance with religious corridors [22].

In fact, Halal Tourism is not related to Muslims alone. That is, Halal Tourism can be tilled, enjoyed until it is made a strong economic projection by non-Muslims too. Muslim majority countries and Muslim minorities can still work on Halal Tourism projections, and this is the current trend, as is the case in Thailand, Japan, South Korea, Singapore, New Zeland, and many more [23]. Non-Muslims can continue to enjoy Halal Tourism as long as it does not contradict what has been believed. According to [24] for non-Muslim tourists, Halal Tourism is health insurance through halal products offered. In addition, Halal Tourism also provides an alternative choice for non-Muslim tourists who expect a health-conscious life during a tour and want a new experience in enjoying the social culture that is based on Islamic principles [18]. Even a study conducted on Christian and atheist tourists, the majority of them consider Halal Tourism is not a problem in the sense that they can enjoy it because it is regarded as a meaningful experience [14]. 
According to the benefits provided by Halal Tourism for both Muslim and non-Muslim tourists [25], it is not difficult to say that, from the perspective of the future, Halal Tourism is a promising market. This destination can be addressed universally to Muslims and non-Muslims with no element of racial violence [24].

\section{Economic Opportunities in Halal Tourism Trend}

The world's Muslim population is growing very rapidly. PEW Research predicts that by 2050 Muslim growth will reach 2.8 billion with the most productive birth rate when compared to other religions in the world. It seems that this increase is in line with the global halal market demand growth. [26] said the growing demand for halal products and services amid the everincreasing Muslim population has opened up new opportunities to develop the supply of Muslim needs, including Halal Tourism.

Muhamad et al. dubbed Halal Tourism as a new billion-dollar travel trend [26]. This is undeniable because, indeed, Muslim consumers are one of the fastest-growing market segments today [27]. Based on this, Halal Tourism has received special attention from businesses in Muslim majority- and Muslim minority-populated countries [26]. They are grappling with the development plan for Halal Tourism and its policies by balancing the economic and social benefits that will be generated [28] to compete for the income of USD 220 billion from 160 million Muslim tourists in 2020. Even the nominal is predicted to continue increasing by $6 \%$ per year, so it is anticipated that the amount of Muslim tourist expenditure in 2026 will reach USD 300 billion [6].

As a country with the largest Muslim majority population in the world, Indonesia is not only trying to be a market, but Indonesia also wants to be a producer of world Halal Tourism [29]. For Indonesia, Halal Tourism provides an opportunity to support the economic development of local communities by developing small businesses and creative industries for local communities [24]. During this time the income obtained is quite fantastic, the latest report states that through the Halal Tourism market which grew 15\%, Indonesia won 2.8 million Muslim tourists and generated a foreign exchange of more than 30 trillion Rupiah. Halal Tourism also absorbs a lot of new workers, so the unemployment rate has decreased. That is because the Halal Tourism project opens many industries ranging from halal food and drinks, Muslim-friendly hotels, halal tourism tours, Islamic-themed souvenirs, and much more. Naturally, if the Government of Indonesia is serious about this Halal Tourism project, for example, in the National Medium-Term Development Plan (RPJMN) 2020-2024, tourism (including Halal Tourism) is set as one of the focuses of the nation's economic development program [5].

\section{Motivation Behind Why is Muslim Traveling}

Since ancient times Muslims have traveled, both to tourist destinations and other places. For example, Muhammad (pbuh) traveled from Mecca to Medina for the benefit of Islam, and Muslims made the pilgrimage to Mecca [28,30]. In addition, there are figures in the early history of Islam who travel, and the story is very well known among Muslims namely Ibn Battuta who traveled to all parts of Asia, North and West Africa, and Eastern and Southern Europe from 1325 $\mathrm{AD}$ to $1354 \mathrm{AD}$ and get a warm welcome from the surrounding community $[27,30]$. Then at this time, the Muslims are popular with the term hospitality, which is the activity of visiting relatives 
both inside and outside the city, which is also synonymous with the implementation of the trip with regard to travel.

Muslims are not necessarily fond of a tour, but there is an underlying factor. Aside from being one of the ways to relieve fatigue from routine activities, in fact, the Koran and Hadith, as the highest guidelines for Muslims, also encourage the implementation of tourism activities, namely to travel to various places. One of the verses of the Koran is Al-Mulk verse 15:

"It is He who made the earth tame for you - so walk among its slopes and eat of His provision and to Him is the resurrection."

It is not uncommon for Muslims to travel to find out the various creations of Allah SWT, ranging from the many races, ethnicities, cultures, and skin colors to make them think of His greatness.

However, the availability of tourism destinations is often not following the norms contained in Islamic law, such as the existence of pornography to gambling. In addition, tourism destinations located in Muslim minority areas are often unable to accommodate the needs of Muslims, such as the lack of infrastructure for purification and prayer. Therefore, the concept of Halal Tourism emerges to provide an alternative amid the rise of hedonic tourism [28]. So that the basic needs of Muslims relating to daily worship can still be adequately accommodated during a tour.

\section{Methodology}

This study is a qualitative study that reviews the literature in the form of journals regarding Halal Tourism, documents issued by the Government of Indonesia regarding the strategy for developing Halal Tourism, and reports from global organizations relating to the assessment of Halal Tourism and religious projections in the world. Quantitative data analysis is also carried out through data released by the Government of Indonesia and global organizations. This study was carried out as an effort to increase the repertoire of knowledge about the development of Halal Tourism, which is based on the acceptance of the community around the development of Halal Tourism destinations.

\section{Discussion}

\section{It's Halal Tourism, not Islamic Tourism}

There are many terms for travel activities undertaken by Muslims, both for spiritual purposes and not. The two terms most widely used in research are Islamic Tourism [15,21], and Halal Tourism [31]. What has become a trend in recent years is not Islamic Tourism but Halal Tourism. That is due to the term Islamic Tourism is more appropriate to be used in journeys for spiritual purposes or the implementation of worship, namely Hajj and Umrah in the holy land of Mecca. Whereas Halal Tourism covers a broader range of activities, namely trips made by Muslims for recreational purposes and intended for worship (such as seeing the creation of Allah SWT to think more about His greatness) to various places in the world, both to Muslimmajority countries and Muslim minorities. During the trip, Muslims try to continue to implement the basics of Islamic law, such as praying, covering the genitals, and eating halal food. 
In a simple term, the activities in Halal Tourism can also be carried out by non-Muslims, but not with activities in Islamic Tourism, namely carrying out Hajj and Umrah, which must be preceded by becoming adherents of the Islamic religion (say two sentences of shahada). Activities in Halal Tourism include the consumption of halal food, the provision of hotel accommodation, and Muslim friendly transportation, which can also be enjoyed by non-Muslims for several reasons [32]. Even in the perspective of economic opportunities, the provision of the needs of Muslims during a tour can also be made by non-Muslims so that it will have a positive economic impact on them [23,33]. From here, it seems too much if you consider the projected development of Halal Tourism destinations in some areas as an effort to Islamization and will damage the existing cultural order. The halal market is indeed the belle of many countries, including Muslim minority countries. The proof, New Zeland, as a country with a Muslim minority, occupies the highest halal exporters [33]. In addition, other Muslim minority countries such as Thailand and Singapore also compete to provide the best service for Muslim tourists [34].

\section{The Reasons Why Halal Tourism Concept Rejected}

The Indonesian government's effort to encourage the Halal Tourism establishment in some areas seems to face issues. The challenges come from the rejection of the society surrounded the Halal Tourism destination project. A document from Indonesia Islamic Masterplan in 2019-2024 mentions eight provinces forecasted to be the Halal Tourism destination, namely Aceh, North Sumatera, West Java, East Java, Yogyakarta, West Nusa Tenggara, South Sulawesi, and South Kalimantan. However, in the recent implementation, there are eight different provinces adopted as Halal Tourism destinations, namely Aceh, Bali, Jakarta, West Java, East Java, West Nusa Tenggara, Riau, and West Sumatera. Each of these provinces possesses different excellences, such as in nature tourism, artificial tourism, cultural tourism, and culinary. The provinces projected to be Indonesia Halal Tourism destination manifested in the 2019-2024 Halal Tourism Development Strategy blueprint are illustrated in Fig. 1.

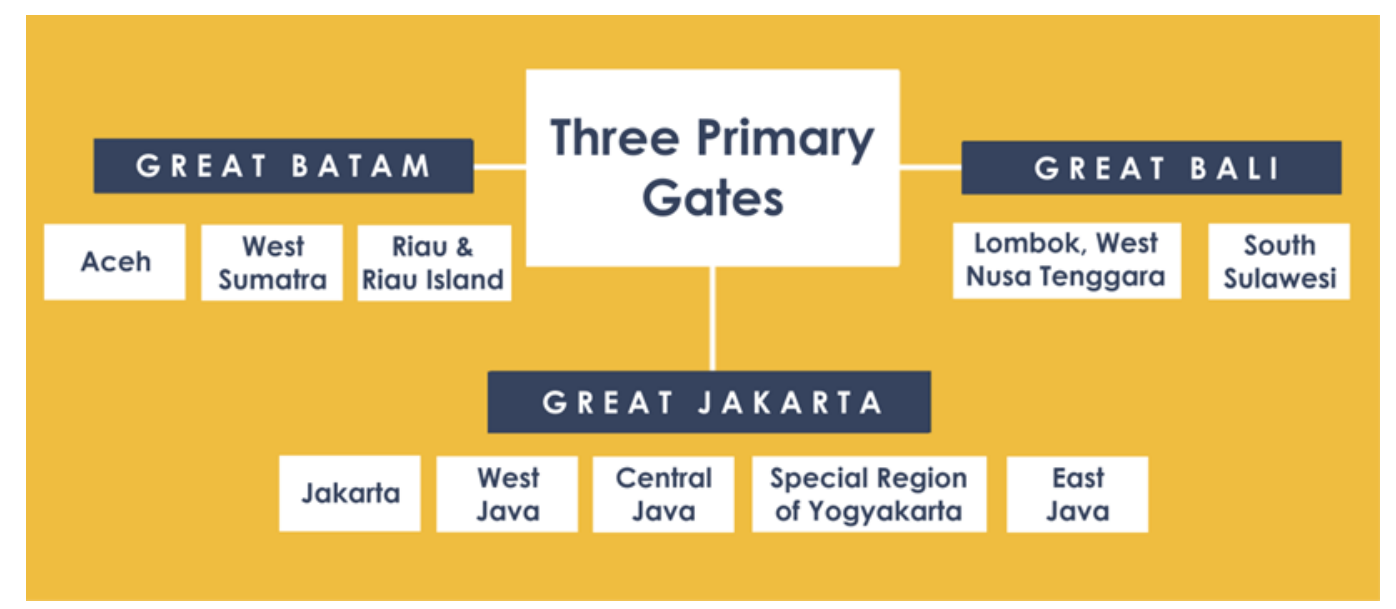

Figure 1. 10 Projected Halal Tourism Destination through Three Primary Gates. Source: 20192024 Halal Tourism Development Strategy Blueprint

From those eight projected destinations, the two already implemented areas face social rejection, North Sumatera and Bali. As the development progressed, the newly joined projected destination, East Nusa Tenggara, also encounter exclusion. The society mentions that the Halal 
label contradicts the surrounding society's culture. They even suggest that the Halal Tourism notion may only damage the diversity.

Additionally, the rejection also comes from college students who held a strike carrying a banner that reads, "Lake Toba Needs No Halal Label." They state that the implementation of Halal Tourism will disturb the society that has lived in harmony [35]. A similar idea is also expressed by Samosir Regent and one legislative member of North Sumatera. They explicitly refuse the Halla Tourism destination project in Lake Toba due to it is not in accordance with the Indonesia National motto, Bhinneka Tunggal Ika.

In addition, the Halal Tourism destination project in Bali was first brought up by one of Indonesia politicians, Sandiaga Uno [36]. He identifies a relatively broad economic opportunity on Bali's Halal Tourism destination project. A similar opinion was also mentioned by the Minister of Tourism and Creative Economy, Wishnutama, even if he later clarified that he was not suggesting the idea [37]. Additionally, Bali Governor, I Wayan Koster, and one of the Bali tourism figures, Gede Wiratha, also rejects the idea. Gede Wiratha declared that the concept is not acceptable since Bali has been famous for its cultural tourism and will continue to maintain that branding, not religious tourism [9]. The head of ASITA (Association of the Indonesian Tours and Travel) Bali, I Ketut Ardana, also articulates the same reason for his rejection [36].

Further, Labuan Bajo, located in East Nusa Tenggara, is recently projected as one of the Halal Tourism destinations. However, that concept was straightly rejected by East Nusa Tenggara Governor Viktor Laiskodat. He explained that Halal Tourism development in Labuan Bajo would provoke conflict within the tourism business that propagate other social conflicts [38]. In social media, a lot of Indonesia people refuse the idea and hold discussions on this topic.

Therefore, the rejection of halal Tourism Destination from the surrounding society is generated by the assumption of Islamisation. This, later, perceives to contradict the existing diversity culture. Further, the application of Islamic values to meet Muslim tourists will dismantle the cultural values and traditions constructed in society. Conversely, Indonesia is a country with millions of diversity with a national motto of Bhinneka Tunggal Ika. Unfortunately, this conflict is materialized from a conceptual misunderstanding of halal Tourism. Meanwhile, Muslim minority countries, such as Japan, China, South Korea, Thailand, Singapore, New Zealand, and so forth, perceive this as an economic opportunity [23,33,34,39].

Halal Tourism is not equal to Islamisation effort since it only accommodates Muslim tourists' demand to practice Islamic Sharia during their travel. Even [31] carefully defines Halal Tourism by considering Islamic laws, costumer targets (Muslim, non-Muslim, or both), destinations (Muslim majority or minority country), the offered products and services, as well as the purpose of the travel. Thus, Halal Tourism is the effort to fulfill the tourist needs to the practice of worship that aims to gain economic revenue; it is not a form of Islamization. That occurs in Indonesia through the concepts provided by the government. 


\section{The Urgency of Segmenting Halal Tourism Destinations and Education Society}

Halal Tourism segmentation in Indonesia experiences social rejection due to the misunderstanding, as well as the majority coming from other religious adherents who have a robust culture. For the success of Halal Tourism destination establishment, the government should consider several aspects in constructing the area segmentation, such as the local culture that possibly gets crumbled if the establishment progressed. Since Indonesia has many potential tourism areas, then Halal Tourism destination can be holistically developed in one area.

That way, the Muslim tourists' needs to comply with Islamic laws can be accommodated. The Muslim tourists' contentments rely on the fulfillment of their demands during their visit to that destination [1,20,40-42]. Once the integrated services related to Halal Tourism are provided, then the Muslim tourists' satisfaction will be accelerated; thus, they will re-visit the destination, and WOM (Word of Mouth) interaction will occur [20,39]. WOM is one of the practical indirect marketing tools for the government in promoting Indonesia Halal Tourism to the world. The segmentation can be conducted by considering the Key Halal Travel Trends in 2019 (Halal Travel 2.0) released by GMTI 2019, as presented in Fig 2.

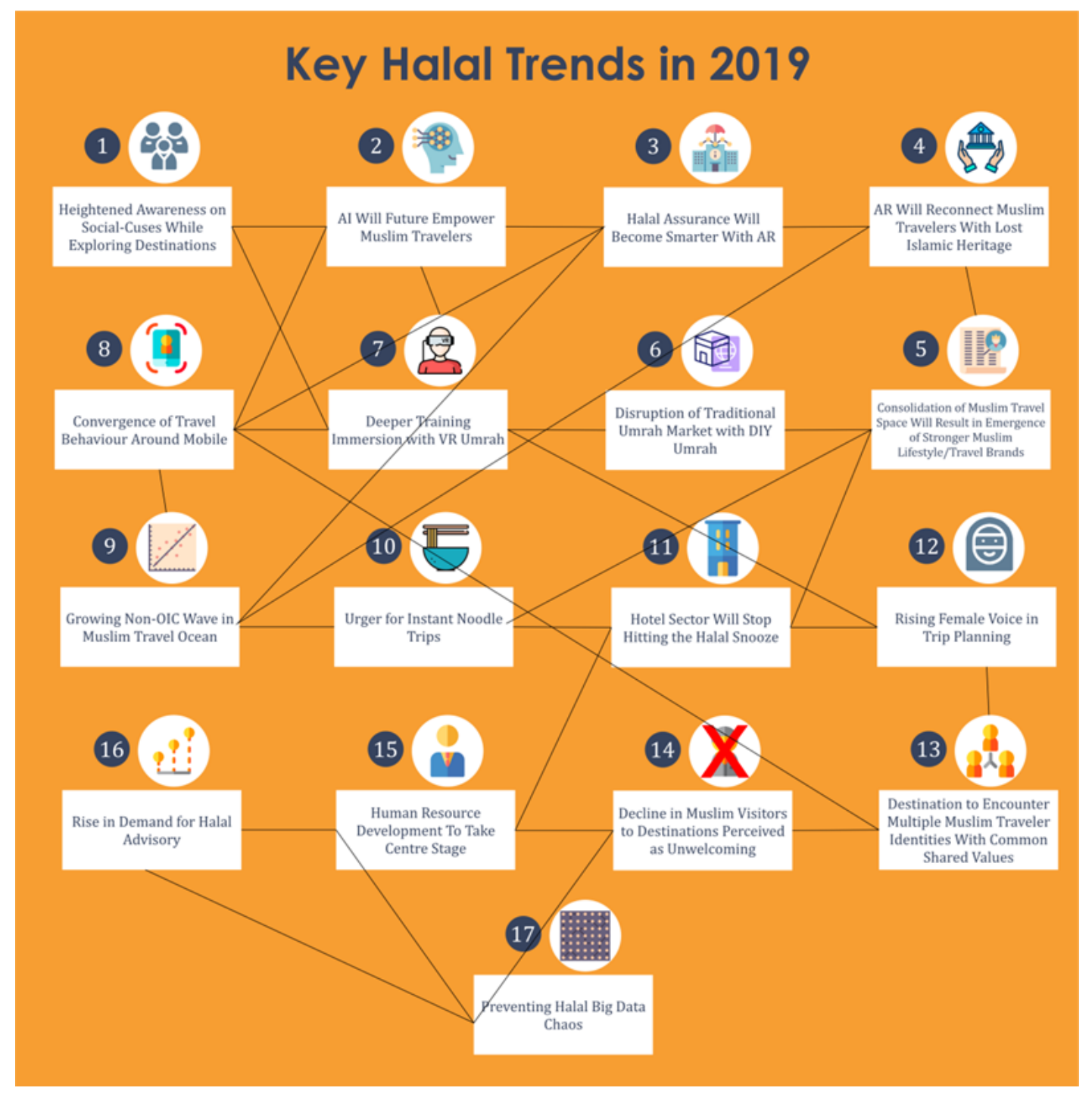

Figure 2. Key Halal Travel Trends in 2019 (Halal Travel 2.0) Source: GMTI Report 2019 
Another critical step is to educate the public about the concept of Halal Tourism. If seen, so far, education has not been so intensively carried out except through several activities such as conferences and seminars in big cities. Meanwhile, segmentation happens not only in big cities but also in areas outside the cities. The official Halal Tourism Indonesia website also does not provide complete information about the concept of Halal Tourism. The website only contains information about destinations that have been implemented in the concept of Halal Tourism and in English. The site is the primary reference of the community at this time in gathering information $[32,43]$ in the era of the Industrial Revolution 4.0. Therefore, efforts to inform the general public through the website must be considered, as can be seen in Fig. 3.

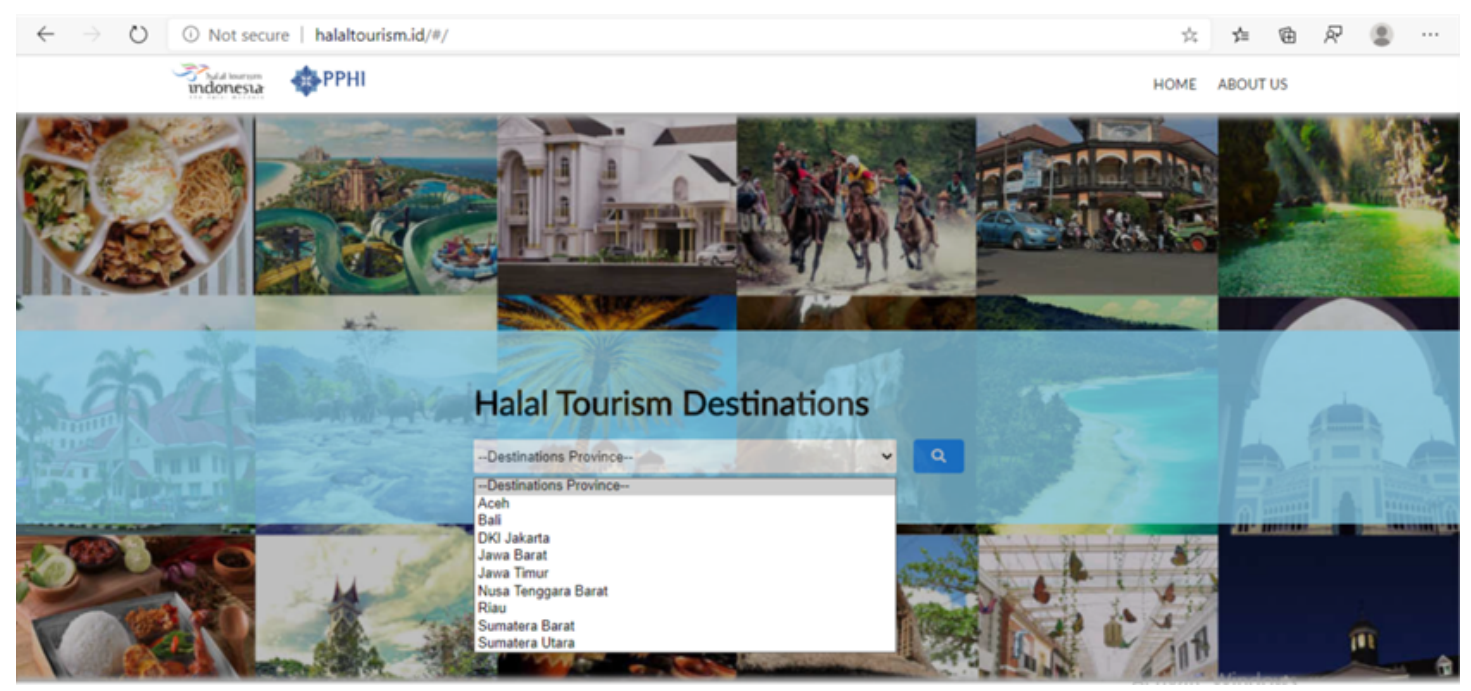

Figure 3. Homepage of the Indonesia Halal Tourism Official Site (halaltourism.id) Source: Website halaltourism.id

On large social media platforms such as YouTube and Instagram that are currently much loved by the public, the Indonesia Halal Tourism related content is not widely available. The current influencers have not had a trend to inform the concept of Halal Tourism in Indonesia so that people do not understand what exists in this concept. In accordance with the 2019-2024 Halal Tourism Development Strategy Plan, the implementation of the promotion will be carried out intensively, but until now, the application has not been very visible. While informing the public is urgent so that Indonesia does not miss the momentum of gaining huge economic profits through the trend of Halal Tourism.

\section{Conclusion}

Many countries are fighting for the eagerness of Muslim tourists from around the world and non-Muslim tourists who have an interest in the hospitality of the concept of Halal Tourism. Indonesia, as a country with a majority Muslim population with a million natural and cultural beauty, joins the competition by preparing a series of strategies to develop Halal Tourism destinations in several regions. This is very reasonable considering that Halal Tourism has proven to open up economic revenue for many countries, even Halal Tourism is also a place to promote the country's natural and cultural wealth and to open job vacancies for many unemployed people. Unfortunately, the efforts made by the Indonesian government did not go smoothly. The community around the Halal Tourism destinations rejects the project due to discrimination and incompatibility with the native culture of the region. This rejection by the 
community is one of the challenges for the Government of Indonesia in developing Halal Tourism destinations given the many economic benefits to be gained. The analysis discovers the actual rejection comes from a misunderstanding between the community, the government, and the lack of a Halal Tourism education strategy to the public. Many prominent figures from the local environment, such as Lake Toba, North Sumatra, and Bali, do not understand the concept of Halal Tourism holistically. In addition, people who tend to be rash in commenting on the development of Halal Tourism destinations project have made the situation worse. The government is also considered lacking in promoting Halal Tourism, which brings a lot of economic benefits.

\section{References}

[1] R. Eid and H. El-Gohary, "The role of Islamic religiosity on the relationship between perceived value and tourist satisfaction," Tour. Manag., vol. 46, no. February 2015, pp. 477-488, 2015.

[2] S. M. Isa, P. N. Chin, and N. U. Mohammad, "Muslim tourist perceived value: a study on Malaysia Halal tourism,” J. Islam. Mark., vol. 9, no. 2, pp. 402-420, 2018.

[3] T. Warsito, A. Maksum, S. Surwandono, and R. Herningtyas, "Tourism Relations from the Perspective of Foreign Policy," Int. J. Innov., vol. 9, no. 6, pp. 89-100, 2019.

[4] Thomson Reuters \& Dinar Standard, "State of the Global Islamic Economy Report 2018/19." 2018.

[5] Deputi Bidang Pengembangan Industri dan Kelembagaan Kementrian Pariwisata Indonesia, "Rencana strategi pengembangan pariwisata halal 2019-2024." 2019.

[6] Global Muslim Travel Index, "Mastercard - CrescentRating report.” 2019.

[7] Indonesian Ministry of National Development Planning, "The Indonesia Masterplan of Sharia Economy 2019-2024." 2019.

[8] The Jakarta Post, "Peppa Pig selfies: Distrust hurdle to halal tourism," 2019.

[9] Pos Bali, “Tokoh Bali Nilai Wishnutama Tak Paham Pariwisata Budaya.," 2019.

[10] R. C. Paddock, "Indonesia Wants 'Halal Tourism.' But Some Want to Wrestle Pigs," nytimes.com, 2019.

[11] D. Irmanti, M. R. Hidayat, N. V. Amalina, and D. Suryani, "Mobile smart travelling application for indonesia tourism," Procedia Comput. Sci., vol. 116, no. 2017, pp. 556-563, 2017.

[12] H. Zamani-Farahani and R. Eid, "Muslim world: A study of tourism \& pilgrimage among OIC Member States," Tour. Manag. Perspect., vol. 19, no. Part B, July 2016, pp. 144-149, 2016.

[13] A. H. B. A. Aziz, "Muslim Friendly Tourism: Concept, Practices and Challenges in Malaysia," Int. J. Acad. Res. Bus. Soc. Sci., vol. 8, no. 11, pp. 355-363, 2018.

[14] M. Battour, F. Hakimian, M. Ismail, and E. Boğan, "The perception of non-Muslim tourists towards halal tourism," J. Islam. Mark., vol. 9, no. 4, pp. 823-840, 2018.

[15] E. Boğan and M. Sarışı1k, "Halal tourism: Conceptual and practical challenges," J. Islam. Mark., vol. 10, no. 1, pp. 87-96, 2019.

[16] S. D. Khoiriati, I. M. Krisnajaya, and D. Dinarto, "Debating halal tourism between values and branding: a case study of Lombok, Indonesia,” in KnE Social Sciences, 2018, pp. 494-515.

[17] E. Izberk-Bilgin and C. C. Nakata, "A new look at faith-based marketing: The global halal market," Bus. Horiz., vol. 59, no. 3, pp. 285-292, 2016.

[18] H. G. Olya and A. Al-ansi, "Risk assessment of halal products and services: Implication for tourism industry," Tour. Manag., vol. 65, no. April 2018, pp. 279-291, 2018.

[19] M. Battour, Muslim travel behavior in Halal tourism. Leszek Butowski, IntechOpen, 2018.

[20] Y. Wardi, A. Abror, and O. Trinanda, "Halal tourism: antecedent of tourist's satisfaction and word of mouth (WOM)," Asia Pacific J. Tour. Res., vol. 23, no. 5, pp. 463-472, 2018.

[21] M. Carboni, C. Perelli, and G. Sistu, "Is Islamic tourism a viable option for Tunisian tourism? Insights from Djerba," Tour. Manag. Perspect., vol. 11, no. July 2014, pp. 1-9, 2014.

[22] A. Vargas-Sánchez and M. Moral-Moral, "Halal tourism: Literature review and experts' view," J. Islam. Mark., vol. 11, no. 3, pp. 549-569, 2019.

[23] H. Han, A. Al-Ansi, H. G. Olya, and W. Kim, "Exploring halal-friendly destination attributes in South Korea: Perceptions and behaviors of Muslim travelers toward a non-Muslim destination," Tour. Manag., vol. 71, no. April 2019, pp. 151-164, 2019.

[24] A. Wijayanti, H. Widyaningsih, M. F. Hakim, and M. A. Fiyan, "Past, Present, and Future Perspectives on The Concept of Halal Tourism," 2019. 
[25] A. Jaelani, "Halal tourism industry in Indonesia: Potential and prospects," Int. Rev. Manag. Mark., vol. 7, no. 3, pp. 1-19, 2017.

[26] N. S. A. Muhamad, S. Sulaiman, K. A. Adham, and M. F. Said, "Halal Tourism: Literature Synthesis and Direction for Future Research.," Pertanika J. Soc. Sci. Humanit., vol. 27, no. 1, pp. 729-745, 2019.

[27] M. L. Stephenson, “Deciphering 'Islamic hospitality': Developments, challenges and opportunities," Tour. Manag., vol. 40, no. February 2014, pp. 155-164, 2014.

[28] J. Jafari and N. Scott, "Muslim world and its tourisms," Ann. Tour. Res., vol. 44, no. January 2014, pp. 1-19, 2014.

[29] I. Firdausi, S. Marantika, Z. N. Firdaus, and R. Sajidah, "Lombok: Halal tourism as a new Indonesia tourism strategy," in International Conference on Humanities, 2017, pp. 13-14.

[30] H. El-Gohary, "Halal tourism, is it really Halal?," Tour. Manag. Perspect., vol. 19, no. Part B, July 2016, pp. 124-130, 2016.

[31] M. Battour and M. N. Ismail, "Halal tourism: Concepts, practices, challenges and future," Tour. Manag. Perspect., vol. 19, no. July 2016, pp. 150-154, 2016.

[32] M. Suradin, "Halal tourism promotion in Indonesia: An analysis on official destination websites," J. Indones. Tour. Dev. Stud., vol. 6, no. 3, pp. 143-158, 2018.

[33] S. Razzaq, C. M. Hall, and G. Prayag, "The capacity of New Zealand to accommodate the halal tourism market —or not," Tour. Manag. Perspect., vol. 18, no. April 2016, pp. 92-97, 2016.

[34] J. C. Henderson, "Halal food, certification and halal tourism: Insights from Malaysia and Singapore," Tour. Manag. Perspect., vol. 19, no. Part B, July 2016, pp. 160-164, 2016.

[35] Ngelmu, "Saat Negara Lain Terapkan Wisata Halal, Mengapa Indonesia Menolak?," ngelmu.co, 2019.

[36] A. Mardiastuti, "Pengusaha Ramai-ramai Tolak Ide Sandi soal Wisata Halal Bali," detik.com, 2019.

[37] Detiknews, "Wishnutama Angkat Bicara soal Isu Bali Jadi Wisata Halal,” detik.com, 2019.

[38] Harnas, "NTT Tolak Label Wisata Halal Labuan Bajo," harnas.co, 2019.

[39] N. Akhtar, J. Sun, W. Ahmad, and M. N. Akhtar, "The effect of non-verbal messages on Muslim tourists' interaction adaptation: A case study of Halal restaurants in China," J. Destin. Mark. Manag., vol. 11, no. March 2019, pp. 10-22, 2019.

[40] N. Abdullah, "Impact Satisfaction Factors of Ecotourism for Sustainable Tourism Business and Management," Int. J. Innov., vol. 10, no. 10, pp. 161-177, 2020.

[41] A. Abror, Y. Wardi, O. Trinanda, and D. Patrisia, "The impact of Halal tourism, customer engagement on satisfaction: moderating effect of religiosity," Asia Pacific J. Tour. Res., vol. 24, no. 7, pp. 633-643, 2019.

[42] A. Al-Ansi, H. G. Olya, and H. Han, "Effect of general risk on trust, satisfaction, and recommendation intention for halal food," Int. J. Hosp. Manag., vol. 83, no. October 2019, pp. 210-219, 2019.

\section{Corresponding author biography}

Madziatul Churiyah obtained his S.Pd, in 1999 from Institut Keguruan dan Ilmu Pendidikan (IKIP) Malang and M.M. degree in from Universitas Brawijaya (UB). She received his Dr. degree from Universitas Negeri Malang (UM) in 2015. Her expertise is in the field of business management education. 